\title{
Jarosław Ławski*
}

\section{Wielkie stulecie Polaków. Wiek XIX - koniec lektury?}

DOI: http://dx.doi.org/10.12775/LC.2016.051

Mitość łączy świętych w niebie - nienawiść rozdziela potępionych.

Antoni Szlagowski ${ }^{1}$

Streszczenie: Autor omawia stan badań nad literatura polską XIX w. w szerokim kontekście europejskiej humanistyki oraz aktualnych wyzwań historycznoliterackich i światopoglądowych. Omawia główne kierunki badawcze i zwraca szczególną uwagę na potrzebę nowych płaszczyzn dialogu $\mathrm{z}$ romantyzmem. Zdaniem badacza, twórcza rozmowa z epoką nie może pomijać kontekstu historycznego dawnych dzieł oraz biografii ich twórców, powinna natomiast uwzględniać problematykę poszukiwania tożsamości wspólnoty. Autor podkreśla m.in. ważną dla zrozumienia tradycji oraz dla podtrzymania z nią związków rolę dyskursów większościowych: patriotycznego i mesjanistycznego, religijno-metafizycznego i prowidencjalistycznego, przysłoniętych przez eksponowane w najnowszych badaniach dyskursy mniejszościowe.

Słowa kluczowe: wiek XIX, poezja romantyczna, proza XIX wieku, synteza historycznoliteracka, dyskursy mniejszościowe, dyskursy większościowe, patriotyzm, mesjanizm, emancypacja

Abstract: Author discusses the state of art of the study of XIX ct Polish literature against the broad context of European humanities, as well as contemporary debates among historians of literature and conflicting worldviews. He pays particular attention to the need for new platforms of a dialogue with romanticism. According to him, a fruitful conversation with this epoch cannot ignore the historical context of old works and biographies of their creators; indeed, it should acknowledge the search for collective identity. Author stresses the role of majority discourses: patriotic and messianistic, religio-

\footnotetext{
* Profesor zwyczajny, kierownik Katedry Badań Filologicznych „Wschód-Zachód”, historyk literatury w Instytucie Filologii Polskiej na Uniwersytecie w Białymstoku. E-mail: jlawski@wp.pl.

** Wykład wygłoszony w 2014 roku w Toruniu.

1 Ks. A. Szlagowski, Wady i przymioty woli ludzkiej rozebrane na tle Męki Pańskiej w sześciu konferencjach pasyjnych w kościele Św. Józefa Oblubieńca (po-Karmelickim) w Warszawie roku 1899, Warszawa 1900, s. 15.
} 
us-metaphysical and providentialist in understanding and keeping up with tradition, discourses that in recent research have been dominated by minority discourses.

Keywords: Polish literature, XIX century, romantic poetry, XIX ct prose, historical-literary syntesis, minority discourses, majority discourses, patriotism, messianism, emancipation

\section{Diagnoza}

badaniami nad literaturą i kulturą XIX w., rozumianego szeroko jako formacja rozciągająca się między 1795 a 1918 r., jest Anno Domini 2012 źle. To naturalny stan i proces. Romantyzm i druga połowa XIX stulecia stanowily dla całej formacji XX-wiecznej zasadniczy - afirmowany lub negowany - punkt odniesienia. Już w 1923 r. Wacław Lednicki, który w okopach I wojny światowej szukał wartości w dziełach Alfreda de Vigny’ego, ubolewał nad pustką powojennej rzeczywistości: „Literatura ta jest wyrazem tendencyj nowego pokolenia, które pragnie odwrócić się od katastrofy, dopiero co minionej. W tej literaturze, jak w fox-trott'cie, społeczeństwo dzisiejsze znajduje zapomnienie przeszłości, obok pobudzenia do chwytania łatwych uciech i radości, jakie życie dać może. Czy takie jest jednak zadanie poezji i prawdziwej powieści?"”. Ale przyszły jedna po drugiej wielkie i straszne polskie daty: 1939, 1945, 1948, 1956, 1968, 1970, 1976, 1980, 1981, 1989 - i wciąż formacja romantyczna miała się wcale dobrze, ożywiana przez impulsy patriotycznej aktywności, wolnościowe idee.

Wreszcie nadciągnęła wolność i znów, jak by rzekł Lednicki, zatańczyliśmy „fox-trott’a”. Także badawczego. Maria Janion ogłosiła „zmierzch paradygmatu romantycznego”, badacze chwycili się nowych, idących z Zachodu inspiracji dekonstrukcją, poststrukturalizmem, myślą Derridy, Foucaulta, Rorty’ego, Vattima, Gaertza, White’a. Jakoby odeszły w przeszłość „wielkie narracje” i gatunki, w pisarstwie historycznym odkryto element narratywistyczny, kto żyw badał mapy; dekolonizowano, co tylko można z polskiej tradycji XIX-wiecznej, a „Inny” stał się po prostu podstawową figurą człowieka, jakkolwiek zapominano, że ten antropologiczny konstrukt ma sens tylko wobec „nie-Innego”, zwyczajnego, tutejszego. Odkryto dyskursy mniejszościowe - o dziwo, tylko niektóre: kobiecy, żydowski, mniejszościowy (także homoerotyczny), transgresyjny.

Avant la lettre pisarze i pisarki awansowali na prekursorów lub wsteczników sub specie nowoczesności. Słowacki bezżenny, Żmichowska transgresyjna, Konopnicka jako partnerka Dulębianki, Prus jako piewca nowoczesności, Mickiewicz jako prefeminista, Krasiński $\mathrm{w}$ roli pre-camusowskiego egzystencjalisty, Odyniec jako poeta biedermeieru w czasach, gdy biedermeieru jeszcze nie było, Miciński pogrążony w kabale, Zapolska jako ułomna, bo nieprzekonana emancypantka i feministka, Norwid jako krypto-nihilista, Mickiewicz i zesłańcy na Sybir jako nowocześni turyści, odbywający podróże światoznawcze, Kraszewski,

\footnotetext{
2 W. Lednicki, Alfred de Vigny. Z historii pesymizmu religijnego, Warszawa 1923, s. VI.
} 
Fisz i Padurra jako polskojęzyczni pisarze ukraińscy, wreszcie Karol Wojtyła jako epigon archaicznego romantyzmu - wszystkie te konstatacje i opisy zasiliły skarbiec ponowoczesnego literaturoznawstwa.

Zauważmy, iż zniknęły w ogóle zjawiska, które określały historyczne i kulturowe hic et nunc XIX w.: stosunek do powinności patriotycznej, ziemi, religii i wiary, odmienności kulturowej i religijnej Rosjan, Niemców i Austriaków, rodzących się nacjonalizmów litewskiego, ukraińskiego, białoruskiego, słowackiego i łotewskiego, do wielkich projektów przemiany obrazu Europy i świata, mesjanizmu i postyczniowych utopii, kobiety, dziecka i mężczyzny, indywidualnych poszukiwań prawdy o świecie, graniczących z heterodoksją, ducha, duszy i ciała, mesjanizmu i idei słowiańskiej, Rzymu i Bizancjum, kolejnych traum porozbiorowej, ponapoleońskiej, polistopadowej, po Wiośnie Ludów, postyczniowej, po Sedanie, po rewolucji $1905 \mathrm{r}^{3}$

Wszystko pochłonęła ekstaza de- i re-kompozycji, -konstrukcji, -semantyzacji kanonu dzieł i tematów, metodologicznego neo- i post-innowacjonizmu. Było to doświadczenie konieczne, ale też bardzo ożywcze. Do pewnego momentu. Trwanie długie tych odnowicielskich i demaskatorskich, lecz wtórnych wobec Zachodu tendencji - jest szkodliwe. Jeszcze w 2000 r. pisałem, że po 2000 r., po wielkim święcie millenium, wiek XIX stanie się - w irracjonalny sposób - czymś dalekim, oddalonym od nas o wiek, za siedmioma górami, za siedmioma lasami ${ }^{4}$. I tak się stało. Akcja ratownicza, jaką podjęto wobec XIX i XX w., polegająca na przyłożeniu do XIX stulecia kategorii (pre-)nowoczesności, dziewiętnastowieczności, a do formacji XX-wiecznej klucza modernizmu, wydaje się naiwna.

W abstrakcjach - choć dobrze brzmią - to giną, to wypływają na widok konkretne zjawiska, poddane ideologicznemu terrorowi wartościowania jako nowoczesne lub nienowoczesne. A co z resztą? Z nienowoczesnymi? Z Woroniczem, Koźmianami, Rufinem Piotrowskim, Kajetanem Suffczyńskim, Teodorem Jeske-Choińskim, Wagą, Ludwikiem Powidajem, Jadwigą Rostworowską, Ignacym Chodźką, Henrykiem Rzewuskim, Adamem Szymańskim i legionem całym - z Kraszewskim, Kaczkowskim, Jeżem, Zachariasiewiczem, Glińskim, Sołtanem, Korwin-Małaczewskim i Wiśniowskim na czele? Co z nimi?

Z drugiej strony ideologicznego szańca powołano tyranię tradycji - dobrzy są ci, którzy pielęgnują postsarmacką tradycję, wartości ziemiańskie, rzymskokatolicką wiarę przodków i „centrum polskości”. Co wtedy z Julianem Klaczką i Edmundem Chojeckim, Antonim Baranowskim (Antanasem Baranauskasem) i Władysławem Syrokomlą (dla Białorusinów to Białorusin), co $\mathrm{z}$ transgresyjnymi herezjotwórcami: Słowackim, Żmichowską, Przybyszewskim od chuci, Licińskim od lumpenproletariackich ekscesów, a nawet co z za kołnierz niewylewającą Cyganerią warszawską i Stanisławą Przybyszewską?

3 Por. tomy jakże inne: I. Iwasiów, Gender dla średnio zaawansowanych. Wyktady szczecińskie, Warszawa 2004; Adam Mickiewicz. Dwa wieki kultury polskiej. Studia, red. K. Maciąg, M. Stanisz, Rzeszów 2007. I parę

ksiąg: Odmiany odmieńca. Mniejszościowe orientacje seksualne $w$ perspektywie gender, red. T. Basiuk, D. Ferens, F. Sikora, Katowice 2002; Ethos literatury w niespokojnym świecie, red. E. Feliksiak, Białystok 1989.

${ }^{4}$ J. Ławski, Życie i śmierć mitu. „Faust polski” między XIX a XXI wiekiem, w: Postacie i motywy faustyczne w literaturze polskiej, t. 2, red. H. Krukowska i J. Ławski, Białystok 2001, s. 629. 


\section{Tow. Literackie im. Adama Mickiewicza \\ Oddział w Toruniu}

\section{CYKL ODCZYTÓW O SIENKIE WICZU}

Oddział Toruński Towarzystwa Literackiego im. Adama Mickiewicza urzadza cykl. odczyłów - Sienkiewiczu, kłóre odbywać się będa w sali V Collegium Maius Uniwersytetu Mikołaja Kopernika (Toruń, ul. Fosa Staromiejska 3, I. p.) o godz. 19-tej w następriych dniach:

\begin{tabular}{|c|c|c|c|}
\hline 1 & $\begin{array}{c}\text { poniedzialek } \\
21 . \text { I. } 57\end{array}$ & $\begin{array}{l}\text { Dr Bronisław Nadolski } \\
\text { prof. U. M. K. }\end{array}$ & $\begin{array}{l}\text { Sienkiewicz w suietle swej korespodencji z } \\
\text { pisarzami, uczongmi i wydawcami }\end{array}$ \\
\hline 2 & $\begin{array}{l}\text { poniedzialek } \\
28 . \text { I. } 57\end{array}$ & $\begin{array}{l}\text { Mgr Jarosław Maciejewski } \\
\text { adiunkt Uniwer. Poznanskiego }\end{array}$ & „Za chlebem“ Sienkiewicza \\
\hline 3 & $\begin{array}{l}\text { piątek } \\
\text { I. II. } 57\end{array}$ & $\begin{array}{l}\text { Dr Andrzej Bukowski } \\
\text { docent U. M. K. }\end{array}$ & Nowelistyka Sienkiewicza \\
\hline 4 & $\begin{array}{l}\text { piątek } \\
\text { 8. II. } 57\end{array}$ & $\begin{array}{l}\text { Mgr Anna Krzewińska } \\
\text { asystent U. M. K. }\end{array}$ & „Liśty z Ameryki“ Sienkiewicza \\
\hline 5 & $\begin{array}{l}\text { piątek } \\
\text { 15. II. } 57\end{array}$ & $\begin{array}{l}\text { Mgr Antonina Bartoszewicz } \\
\text { starszy asystent U. M. K. }\end{array}$ & „Trylogia“ w swietle dotychczasowych badań \\
\hline 6 & $\begin{array}{l}\text { piątek } \\
\text { 21. II. } 57\end{array}$ & $\begin{array}{l}\text { Dr Artur Hutnikiewicz } \\
\text { docent U. M. K. }\end{array}$ & Sienkiewicz a Młoda Polska] \\
\hline 7 & $\begin{array}{l}\text { piątek } \\
\text { 29. Il. } 57\end{array}$ & $\begin{array}{l}\text { Mgr Czesław Niedzielski } \\
\text { starszy asystent U. M. K. }\end{array}$ & Poglądy estetyczne Sienkiewicza \\
\hline
\end{tabular}

Prelekcje przeuidziane są dla szerszych kół społeczeństua, inauczycieli, „młodzieży akademickiej i licealnej. Zarząd Towarzystua prosi o wzięcie w nich udziału.

\section{ZA ZARZAD}

(-) mgr Franciszek Pepłowski

(-) prof. Bronisław Nadolski

vMK E-t-11 - 16.1. 5

Program cyklu odczytów o Sienkiewiczu w 1957 roku w Towarzystwie Literackim im. Adama Mickiewicza w Toruniu, 1957, fot. Archiwum UMK 
Spór Oświecenia i Tradycji sparaliżował w końcu i literaturoznawstwo, i refleksję społeczną ${ }^{5}$. W 2011 i 2012 r. badacz zajmujący się XIX w. był w dyskomfortowej sytuacji ideologicznego wyboru, ale także smutnego przekonywania siebie i innych, że ta niemodna, „krwawa” i „nacjonalistyczna”, „ksenofobiczna” i „religiancka” epoka ma status epoki już tylko istotnej. Urocze brednie Fukuyamy i Rorty’ego wpoiły przekonanie o końcu historii w demoliberalnym raju Unii Europejskiej. Tymczasem utopia ta rozpadała się w drugim dziesięcioleciu XXI w. w sposób bezprecedensowy. Zapomnieliśmy, że - patrząc z geopolitycznej perspektywy - Warszawę od granicy Białorusi (koło Brześcia) dzieli w prostej linii nie więcej niż sto kilometrów. Historia się nie skończyła i przez wieki nie skończy. „Serce Europy”, którym Norman Davies okrzyknął wciśniętą w skrawek Niżu Środkowoeuropejskiego Polskę, bliskie było zawału. Historia się nie skończyła.

Wiek XIX i XX pozostaną - ale też staropolszczyzna i Oświecenie - skarbem mądrego wyboru postaw, wartości, estetyk, dzieł, autorów nie jako paradygmaty „skończone” lub archiwalne, nie jako paradygmaty totalne, którymi da się diagnozować stulecie XXI, lecz jako paradygmaty żywe. To jest takie, z których w stosownej chwili historycznego komfortu lub depresji dokonujemy wyboru i odnowienia znaczeń fenomenów wtedy nam bliskich. Tak już było i tak będzie nadal. Nawet wartości tyrtejskie ożyły w pamiętnym dniu 13 grudnia $1981 \mathrm{r}^{6}{ }^{6}$, na co patrzyłem bardziej zafascynowany niż przerażony z perspektywy nieco ponadtrzynastoletniego chłopca. Ta pamięć, że nie musi być tak jak dziś, gdy jest miło i mogę pisać szkic o (nie)końcu XIX w., że w jednej chwili wszystko nagle może być inaczej, trwa we mnie już jako nauka historii.

\section{Epikryza}

W jakim stopniu znamy wiek XIX? To wielkie stulecie Polaków ${ }^{7}$, jak pięknie pisała Alina Witkowska, ten wiek Wokulskiego, którego badaniu życie poświecił Józef Bachórz, tę epokę historii i egzystencji, przepatrywaną przez Marię Janion i Marię Żmigrodzką, epokę somnambulików, dekadentów, herosów Marii Podrazy-Kwiatkowskiej, czas traumy porozbiorowej Piotra Żbikowskiego i erę poezji czystej Haliny Krukowskiej, epokę romantycznych bałagułów Stanisława Makowskiego i czasy „bohatera Polaków” Ryszarda Przybylskiego gdzie to stulecie dziś jest? ${ }^{8}$

A bliscy mi - Juliusz Kleiner, Tadeusz Grabowski, Stanisław Brzozowski, Stefan Sawicki i Artur Hutnikiewicz, także Antoni Gustaw Bem i Ludwik Krzywicki, Henryk Galle i lewicujący Andrzej Stawar, Jan Śniadecki i Maurycy Mochnacki, Zofia Szmydtowa i Elżbieta Feliksiak, Antoni Eliasz Łukaszewicz, Józef Kalasanty Szaniawski i Józef Gołuchowski, Anna Libera i Narcyza Żmichowska - łamię chronologię, by z emocją zapytać: gdzie się podziało ich stulecie? Wiek pisarzy, krytyków i badaczy? Stulecie poety, który nauczył mnie

5 Zob. M. Kowalska, Czy trzeba nam więcej agonu? „Ponowoczesna” refleksja o roli konfliktu w kapitalizmie i demokracji, „Przegląd Filozoficzno-Literacki” 2010, nr 4 (29).

6 D. Dąbrowska, Okolicznościowa poezja polityczna w Polsce w latach 1980-1990, Szczecin 1998.

7 A. Witkowska, Wielkie stulecie Polaków, Warszawa 1987.

8 Z procesem ideologicznego prymitywizowania Romantyzmu polemizuję: J. Ławski, Symplifikat. Kartka z dziejów Mickiewiczowskiego mesjanizmu, w: Romantyzm i nowoczesność, red. M. Kuziak, Kraków 2009. 
czytać poezję, Antoniego Malczewskiego, i wiek syna tego geniusza, tragicznego Augusta Antoniego Jakubowskiego? Ubi sunt? Gdzie ich wiek? Myślę, że nowy etap twórczej rozmowy z epoką mogą wyznaczyć i otworzą następujące zjawiska z pola historycznoliterackiej aktywności.

Trzeba, primo, przywrócić cytaty tekstom, teksty ich autorom, autorom ich własne biografie, biografie pisarzy epoce, epoki na powrót wpisać w najszerzej rozumiany kontekst historyczny.

Mickiewicz nie jest patronem neokonserwatystów, ale Konopnicka nie jest też nową Safoną z Lesbos wespół z Rodziewiczówną ${ }^{9}$ Śmieszy mnie wpisywanie życia Żmichowskiej czy Leśmiana w napuszone i tromtadrackie, megalomańskie konteksty dziewiętnastowieczności, nowoczesności, modernizmu, a także w worek bez dna, jakim jest współczesność. Człowiek piszący i niepiszący żyje w określonej niszy pokoleniowej, której żywą granicę wyznacza z jednej strony pamięć przekazana przez pokolenie dziadów i pradziadów oraz pamięć o nich samych, z drugiej świadomość i pamięć o nas pielęgnowane przez naszych wnuków, nade wszystko zaś - jeśli mamy szczęście - ludzie, zdarzenia i wartości, wzory zachowań i wzory ich przełamywania z okresu naszego około czterdziestoletniego, w miarę sprawnego życia dojrzałego. Ojciec mej Matki, Czesław, i dzieci moich Dzieci, Adama i Eli, to już w istocie inne środowisko pokoleniowe - o pierwszym ja pamiętam, ci drudzy, ufam, będą mnie pamiętać. I niewiele tu zmienia elektroniczny nośnik pamięci.

Jak pojąć życie Antoniego Goreckiego, Seweryna Filleborna, Józefa Reitzenheima, Henryka Sienkiewicza, ale i Marceliny Kulikowskiej bez tego żywego kontekstu wartości, estetyk, idei, jaki wyznacza ich otoczenie? Co o nich mówi nowoczesność? Że trzeba czytać, bo my dziś jesteśmy stuprocentowo nowocześni, a oni nas trochę w tym uprzedzili? A co wtedy z ich wewnętrznym strumieniem egzystencji - też był XIX-wieczny? Może uniwersalny? A Leśmian to modernista zapowiadający całą poezję XX w.? Miłosza, Herberta, Ratonia i Zwierzyńskiego, stołecznego Dehnela i kresowego Leończuka, zapomnianą Grossek-Korycką i nieznanego Ilgnera ${ }^{10}$.

Historycy literatury dodają sobie animuszu i splendoru, tworząc te kategorie, które przyszłość zastąpi innymi. Koniec końców rozlegnie się lament jak niegdyś nad strukturalizmem. Rosjanie mówią: wsio proszło! Minie i nowoczesność, zastąpiona kolejnym idolem...

Przywracanie tekstów autorom nie obędzie się bez - czy w ogóle możliwej - jakiejś elementarnej refleksji etycznej środowiska naukowego nad regułami postępowania w warunkach konkurencji o pieniądze na badania i zmiany regul awansu naukowego (zniesienie habilitacji). Jak można badać literaturę w zastępie humanistów, rozdzielając pieniądze między środowiska i ośrodki „wiodące” - Warszawę i Kraków? Taki humanizm własnego interesu skończy się prędzej czy później środowiskową autokompromitacją. Przywrócenie

9 Żenują mnie próby zawłaszczenia Bogu ducha winnych pisarzy przez ideologów. W piśmie feministycznym na zdjęciu z Parady Równości widać manifestantkę niosącą wizerunek Konopnickiej. W „Rycerzu Niepokalanej” (2010, nr 11) zdjęcie pomnika Mickiewicza z grupą manifestantów podpisane jest „Antygejowskie protesty, Warszawa, czerwiec 2006 r.” Odrzuca mnie i jedno, i drugie nadużycie wizerunku artystów słowa.

10 Rzadko badacze zdają sobie sprawę z umowności i doraźności konstruktów. Zob. P. Michałowski, Głosy, formy, światy. Warianty poezji nowoczesnej, Kraków 2008, s. 10: „Doceniając użyteczność sporów periodyzacyjnych, przede wszystkim pamiętać więc warto, iż nowoczesność to ledwie hipoteza badawcza, propozycja interpretacyjna, która jak wszystkie inne tylko w niektórych punktach opiera się na realnym związku z przedmiotem opisu, istniejąc rzeczywiście jako nurt w niektórych manifestacjach artystycznych, w jakichś dominantach autorskich poetyk”. Zob. A. Illgner, Byk, Kraków 2011. 
etycznych standardów i przejrzystych reguł awansu zawodowego - to warunek. Uczony z ubiegającego się o pieniądze ośrodka nie może dzielić beneficjów, bo nie ma takiej możliwości, by - w opinii konkurentów - nie faworyzował kolegów. Habilitacja nie może być gabinetowym wydarzeniem w kole dobrze się znających koryfeuszy dyscypliny.

Przecież nad polskim niedowładem nauki zastanawiano się już na przełomie XIX i XX w., w dwudziestoleciu, współcześnie ${ }^{11}$. I co? Nic. Żadne uzdolnienia i osiągnięcia nie są gwarantem otrzymania środków na badania lub awansu, bo... (zamilknę).

Odwaga metodologiczna! Klucz do odnowy leży w tym, czego sami się boimy: w nowoczesnej formacji naukowej tych, których uczymy sztuki interpretacji. Rozpowszechnione dziś strategie przyswajania obcych metodologii są przerażające: transplantacjonizm każe żywcem przenosić na polski grunt całe metody, wyrobione na potrzeby systemu znaczeń innych niż polska kultur; aplikacjonizm wszczepia w dzieła idee, wartości, struktury, których autor w ogóle nie projektował jako nie tylko pierwszorzędnego, ale bodaj nadczytanego systemu znaczeń (na tej zasadzie Zapolska staje się feministką we współczesnym znaczeniu, dzieło Konopnickiej wyrazem płciowej transgresji, a mesjanizm okazuje się ludobójczą ideologią nacjonalistyczną) ${ }^{12}$. Projektyzm odnajduje najczęściej w przeszłości fenomeny wyobraźni i myśli późniejszych badaczy. Na zasadzie projekcji retrospektywnej Prus to pisarz „nowoczesny”, a Zygmunt Miłkowski przednowoczesny. Na zasadzie projekcji prospektywnej Sienkiewiczowi przykleja się łatę romantycznego mitomana, a ze mnie można zrobić konserwatystę, a nawet neomesjanistę.

Całość tych zabiegów poddana jest jeszcze dwom procesom: ideologicznej metodologizacji (kto nie stosuje „najnowszych” metod badawczych, jest passè i nie dostanie środków na badania) i - obłąkańczemu - ideologicznemu przypisaniu do polskiego literaturoznawstwa nowoczesnego (bada ono literaturę tylko nowoczesną: Leśmiana, Schulza, Witkacego), które jest późnym wnukiem Oświecenia (czytaj: dziewiętnastowieczność, nowoczesność, modernizm, współczesność) lub do postsarmackiej formacji archaicznych historyków literatury, stosujących narzędzia rodem z XIX w., uparcie trzymających się Tradycji (czytaj: archaika kulturowa, nieprzewietrzona przez postęp tradycja, ksenofobiczna narodowość, ludowa i maryjno-infantylna religijność).

W takich warunkach nie sposób pielęgnować Osobowości, nie zaprzedawszy się piewcom Nowego i wciąż Nowszego albo nie okopawszy się w Okopach Św. Trójcy i polskości, co semper fidelis.

Ani kilkusetletnia tradycja, ani wielki patron, sławni mistrzowie, pieniądze i pęd do kariery nie są w stanie wytworzyć Osobowości (ani wiodących katedr), które kiedy i gdzie chcą pojawiają się, by ustąpić miejsca innym Osobowościom. Prawdziwy system naukowy winien tylko wychwytywać i wspierać tych najlepszych. Tak nie jest. Mamy na początku XXI w. w Polsce naukę w najgorszym tego słowa znaczeniu wschodnioeuropejską: $\mathrm{z}$ dominującym ministrem pseudoreformatorem w bizantyjskim stylu, nędznie opłacanymi uczonymi, którzy startują w kuriozalnych zawodach o dotacje. I jeszcze zakulisowy system promocji kadr, już nawet bez jawnej habilitacji.

\footnotetext{
11 Zob. J. Tur, Nauka i uczony, Kraków 1917.

12 Zob. prace pokazujące niekuriozalne elementy twórczości pisarzy: L. Magnone, Maria Konopnicka. Lustra i symptomy, Gdańsk 2011; A. Janicka, Matżeństwo w projekcie emancypacyjnym Gabrieli Zapolskiej, w: Kobieta i matżeństwo. Spotecznokulturowe aspekty seksualności. Wiek XIX i XX, red. A. Żarnowska, A. Szwarc, Warszawa 2004; J. Ławski, Nikt. Czterdzieści i cztery gtupstwa o mesjanizmie, „LiteRacje” 2011, nr 1 (20).
} 
Na nic zdadzą się narzekania na mody intelektualne, jeśli ci, którzy powinni, to jest my sami, nie wychowają śmiałych uczniów, gotowych podjąć w literaturoznawstwie tematyczny i metodologiczny eksperyment; taki, który będzie można zweryfikować, odwołując się do przyjaźnie nastawionych autorytetów, wspierających, a nie gaszących eksperymentatorów.

Moim własnym eksperymentem jest moja samoświadomość badawcza. Nie uważam się za historyka literatury. Nie jestem nim, bo nie chcę. Określam się jako badacz wyobraźni. I wiem, że prawie wszystko zawdzięczam tym wszystkim innym - historykom literatury z różnych frakcji. Ale spojrzenie sub specie badań wyobraźni daje inny ogląd świata idei i obrazów. Gdy patrzę z tego innego miejsca, zrozumiałe staje się dla mnie marzenie Ryszarda Nycza: „Ponownie wstyd powiedzieć, że marzy mi się jej [literatury] opisanie taką, jaką wedle najlepszej naszej wiedzy - po prostu była. To znaczy taką, jaką była za sprawą właśnie tych konkretnych, historycznych, empirycznych okoliczności swego istnienia i realnych warunków rozwoju - a nie swych potencjalnych dyspozycji, wzorców, do których aspirowała, czy ideałów, których miała być depozytariuszką" ${ }^{13}$. Żeby to napisać, tak stwierdzić, trzeba najprzód wyjść z kolein nawyku i zanurzyć się w sferze eksperymentu.

Badacz feminista i dekolonizator, który stwierdza, że nie wszystko pasuje do wzorca przeszczepionej idei, gdy mądry, spamięta tę lekcję, obracając w pożytek uwrażliwienia. Ideolog nie przekroczy progu pętającej go niechęci ku „tym pozostałym”, myślącym inaczej.

Pozwolić młodym na własne poszukiwania metodologiczne przy pełnej świadomości tego, co dzieje się w Ameryce, na Wschodzie i Zachodzie, a nie przenosić, nie przeszczepiać z pozycji pawia i papugi - tak widzę mą utopię. Utopia to nie tylko miejsce, którego nie ma (ou-topos), ale i dobre miejsce (eu-topos).

Dalej: za powyższym powinna pójść zachęta do tworzenia nowych kategorii i pojęć, opisujących to, czego nie chwyta nasz aparat terminologiczny. Sądzę, że kultura od $1918 \mathrm{r}$. przeżywa wyczerpanie kategorialne. Tragizm, egzystencja, podmiot, piękno, sztuka, a nawet nicość i boskość, znaczą już tak wiele, że zbliżają się do semantycznego zera, podczas gdy i w XIX, i w XX w. są zjawiska, których nazwać nie potrafimy, jak porozbiorowa fascynacja plemiennością słowiańską, która nie jest ani słowianofilstwem, ani tym bardziej panslawizmem, a którą sam zwę filosłowianizmem. Jak XX-wieczne estetyki grup transgresyjnych opisywane w kategoriach campu lub wspólnoty tradycjonalistyczne, stygmatyzowane wulgaryzmami lub frazeologizmami („stare próchno”, „mocno starsi”). To samo dotyczy problemów złożonej tożsamości etnicznej (i nie tylko) ${ }^{14}$. Tragiczność, nowe rodzaje piękna, dowartościowana brzydota, odmiany estetyki fantasy, estetyka ekranu komputerowego, progowe stany egzystencji, lot Concorde'a i okrutna, nowoczesna wojna - tych wymiarów nie obejmuje czasem nasz zasób pojęciowy. Mnóstwo zjawisk - mało kategorii. Niepochopna odwaga ich tworzenia powinna zyskać przyzwolenie. Czas zweryfikuje, czy wyczerpanie kategorialne to właściwa konstrukcja na właściwe zjawisko (?).

Trzeba rozwinąć badania nad estetycznymi komponentami świadomości pisarskiej XIX i XX w. Napisać dzieje ironii i (oddzielnie) sarkazmu, absurdu i groteski, frenezji i makabreski, wzniosłości i patosu, centonu i campu, intertekstualności i autointertekstualno-

13 R. Nycz, Możliwa historia literatury, „Teksty Drugie” 2010, nr 5.

14 Zob. W. A. Choriew, Wosprijatije Rossii i russkoj litieratury polskimi pisatieliami, Moskwa 2012; „Kijowskie Studia Polonistyczne”, red. R. Radyszewski, t. XVIII, Kijów 2011; Twórczość Elizy Orzeszkowej w estetycznej przestrzeni wspótczesności, red. S. Musijenko, Grodno 2011. 
ści, ekfrazy i atopii ${ }^{15}$, nekrologu i blogu, określić przemiany debiutu i zamilknięcia, dystopii i fantasy, metamorfozy znaczeń i form juweniliów i seniliów; trzeba dookreślić nowe kategorie, których nam dziś brak na opisanie poetyki i osobowości poezji okolicznościowej, mowy sejmowej czy pisarstwa Placyda Jankowskiego lub Stefana Grabińskiego ${ }^{16}$.

Powinny ożyć badania komparatystyczne i interdyscyplinarne. Ale ich kierunki wyznaczać musi kulturowa geopolityka, lokując strategiczne punkty dialogu, sporu i partnerstwa w przestrzeni kultur: niemieckiej i rosyjskiej, litewskiej i łotewskiej, białoruskiej i ukraińskiej, austriackiej i czeskiej, węgierskiej i rumuńskiej, a także, co zdziwi, szwedzkiej i estońskiej, a także kultur tych krajów, gdzie Polacy stanowią zakorzeniony, nieantagonizujący, twórczy element kultury rodzimej (Ameryka, Brazylia, Niemcy, Francja, Anglia, Australia, Afryka Południowa, Irlandia i Islandia, Norwegia i Kanada). Powinno się przywrócić pogłębioną refleksję nad transferem kulturowym polsko-niemieckim ${ }^{17}$, ale też nad starciem płyt kontynentalnych cywilizacji łacińskiej i bizantyjskiej na wschód od linii Curzona, gdzie trwa fascynujący i groźny proces wykształcania i/lub zanikania tożsamości ukraińskiej, białoruskiej, litewskiej i mołdawskiej, a także dryfuje w obcym środowisku kulturowym rosyjska enklawa obwodu kaliningradzkiego, Królewca, Königsbergu ${ }^{18}$.

Wiele na przełomie XIX i XX w. odkryto i uprawomocniono tzw. dyskursów mniejszościowych. Kobiety, mniejszości narodowe i seksualne, upodleni chłopi (ponieważ polskimi zajęli się marksiści, modne było pochylanie się nad dolą chłopa ukraińskiego i białoruskiego, szczególniej nad Sekwaną i Dnieprem) ${ }^{19}$, demistyfikatorzy polskości i narodowości, byli księża i czerwone hrabiny, lewicowi intelektualiści i „niesłusznie” oskarżani o antysemityzm antysemici - każdemu, co jego. Każdy znalazł protektora. Wydaje się, że w tym błądzeniu po marginesach zgubiono dyskursy większościowe XIX w.: dyskurs patriotyczny i mesjanistyczny, religijno-metafizyczny i prowidencjalistyczny. Wydobyto stłumiony głos kobiet a gdzie podział się i jaki jest podmiot męski: Mickiewicza i Pola, Kremera i Ochorowicza, Czartoryskich i Orkana?

To był wiek nieszczęścia wspólnoty, ale i szczęścia kulturowego bogactwa. Cośmy z niego uczynili? Paradygmat. Nowoczesność przed nowoczesnością. Epokę inności i nacjonalizmu. Wiek wojny Oświecenia i Tradycji. Kikut. Protezę, szkielet tego żywego i ważnego dziś także wieku. Zapytałbym: jeśli mówimy o dyskursach mniejszościowych XIX w., to gdzie na szeroką skalę rozwinięte są badania dyskursów „innych - mniejszościowych”: dyskursu tekstów mistycznych, dyskursu libertyńskiego, wolnomyślicielskiego i ateistycznego, dyskursu agnostycznego (pojęcie tworzy w 1871 r. Thomas Henry Huxley), dyskursu pasyjno-dolorystycznego i żałobnego, dyskursu idei i symboliki wolnomularskiej, dyskursu nihilistów i abnegatów, cyników i tumiwisistów, dyskursu cyganerii i błazenady, dyskursu parodii, pastiszu, satyry, dyskursu idei słowianofilskich, panslawistycznych, dyskursów

15 Zob. A. Dziadek, Atopia. Stadność i jednostkowość, „Teksty Drugie” 2008, z. 1/2.

16 Zob. W. Kalinowski, Noc, marzenie i koszmar senny w twórczości Stefana Grabińskiego, w: Noc. Symbol-Temat-Metafora, t. I: Wokót „Straży nocnych” Bonawentury, red. J. Ławski, K. Korotkich, M. Bajko, Białystok 2011. Wciąż aktualna monografia A. Hutnikiewicz, Twórczość literacka Stefana Grabińskiego. 1877-1936, Toruń-Łódź 1959.

17 Patrz: M. Kopij, Über Imitation zur Kreation. Zur Geschichte des deutsch-polnischen romantischen Kulturtransfers, Leipzig 2011; G. Kowalski, Topika biblijna w twórczości Juliusza Stowackiego i Pära Lagerkvista. Dalekie powinowactwa, w: Noc, t. II, Białystok 2012; J. Ławski, Rok 1819. Pierwszy romantyczny program dramatu narodowego Edwarda księcia Lubomirskiego, w: Noc, t. I.

18 A. Mencwel, Kaliningrad, moja mitość. Dwa pokrewne eseje podróżne, Olsztyn 2003.

19 Zob. polemikę z tezami Daniela Beauvois w: M. Kwapiszewski, Późny romantyzm i Ukraina. Z dziejów motywu i życia literackiego, Warszawa 2006. 
ksenofobicznych (choćby germanofobii i rusofobii, ale też lituanofobii i antysemityzmu), dyskursów filo-odmiennościowych (rusofile i na przykład filosemici), dyskursu renegatów (Sękowski, Bułharyn, Jankowski i inni - jeszcze Conradowi przypisuje Orzeszkowa zdradę), dyskursów pisarzy dwutożsamościowych (pisarze polsko-litewscy, jak Józef Albin Herbaczewski, polsko-białoruscy, jak Jan Czeczot, czy polsko-niemieccy, jak Aleksander Bronikowski, i polsko-ukraińscy, jak Tymko Padurra), dyskursu egzotycznych pisarzy tworzących całe życie poza Europą (nie tylko Domeyko, także podróżnicy, potem Bobkowski), dyskursu podróżopisarzy, pamiętnikarzy, memuarystów.

Gdzie ogromny dyskurs literatury ludowej; dyskurs literatury ludowej z pogranicza (Lompa, Kajka, Gizewiusz, Kolberg) ${ }^{20}$, gdzie dyskurs wspaniałej w tej epoce homiletyki i hagiografii, literatury religijnej ${ }^{21}$. Gdzie dyskurs ezoteryczno- spirytualistyczny, dyskurs utopii scjentystycznych z prac drugiej połowy XIX w. i nieemancypacyjny, tradycjonalistyczny dyskurs kobiet piszących, a gdzie dyskurs zakorzenionych mniejszości orientalnych (Ormian, Karaimów, Greków, Tatarów, Gruzinów)?

Gdzie dyskursy uczonych przyrodników, prawników, ekonomistów będące w XIX w. częścią humanistyki, piśmiennictwa narodowego (Skarbek, Krysiński, Lutosławski).

Gdzie, koniec końców, dyskurs literacki wspaniale zapisanej, przynależącej do literatury pięknej filozofii polskiej XIX w. od Bochwica przez Cieszkowskiego po Abramowskiego i Lutosławskiego? A dyskurs historiografii? Też literacki.

Zgubiliśmy to wszystko, bo pozwoliliśmy, by zapomniano o dyskursach prymarnych: patriotycznym, historycznym, religijnym i pełnym zmagań z sobą, światem i Bogiem dyskursem egzystencjalnym. Pora wrócić. Czas. Wróćmy.

Dopóki nie opuścimy stanowiska absolutnej wtórności wobec idei idących z Zachodu (strukturalizm), południa (marksizm), wschodu (semiotyka), dopóty marzenie o wybijającym się polskim literaturoznawstwie pozostanie mrzonką. Jest jakimś irytującym mitem przekonanie, że literatura narodu tak dotkniętego przez historię musi być hermetyczna, zaściankowa i nic nie ma do powiedzenia Innym. Przede wszystkim niewiele mamy do powiedzenia sami sobie, zakompleksieni, nijacy, nierozpoznawani przez Wschód i Zachód, wstydzący się wszystkiego, co powinno nas wyróżniać z masy kultur: sarmatyzmu i Oświecenia, idei jagiellońskiej, ale i katolicyzmu, romantyzmu i mesjanizmu, a nawet, niech będzie, wiecznej bitwy pod Grunwaldem Oświecenia i Tradycji.

Tak zakleszczeni w figurze Nikogo jesteśmy zmorą dla siebie i bytem niewidocznym dla Innych: Rosjan, Niemców, Francuzów czy Azjatów. Wrodzony, paraliżujący wstyd własnej tożsamości, gorszy niż cielesne obnażenie, i wynikający z niego kompensacyjny bieg przez płotki rozsądku i godności za nowinkami rodem znad Sekwany daje nam takie a nie inne literaturoznawstwo naśladowców, plagiatorów i epigonów, autoepigonów maniery naśladowania. Nie generalizuję, to nie wszyscy tak ..., ale jednak już na początku XIX w. drwił z nas prawdziwy przyjaciel Polaków, niemiecki Żyd, Heinrich Heine, twierdząc, iż Polacy przejeżdżają czym prędzej przez Niemcy jak przez bagnisty kraj, by dotrzeć do stolicy wszystkich wód, pomad i rozkoszy - Paryża ${ }^{22}$.

\footnotetext{
20 G. Kowalski, Zygmunt Gloger. Dzieła - Recepcja - Perspektywy badań, „Bibliotekarz Podlaski” 2011/2012, nr 23/24.

21 Zob. ks. K. Panuś, Zarys historii kaznodziejstwa w Kościele katolickim, cz. II: Kaznodziejstwo w Polsce od Oświecenia do XX wieku, Kraków 2001; Wielcy kaznodzieje Krakowa. Studia in honorem prof. Eduardi Staniek, red. K. Panuś, Kraków 2006; ks. T. Kasabuła, Ignacy Massalski - biskup wileński, Lublin 1998.

22 H. Heine, O Polsce, w: Dzieła wybrane, t. 2, przeł. W. Zawadzki, Warszawa 1956.
} 
Ale, ale... Przecież nie impotencja wstydu sprawia, że nie mamy dziś - jakże zazdroszczę Niemcom i Francuzom ich Gesammelte Werke i Oeuvres complets - dzieł z e b r a n y ch, krytycznych: Zygmunta Krasińskiego, Jana Pawła Woronicza, Kazimierza Brodzińskiego, Maurycego Mochnackiego... Dalej też wyliczam tylko pisarzy dla mnie ważnych: Ludwika Sztyrmera, Placyda Jankowskiego, Wincentego Pola, Władysława Syrokomlę, Dominika Magnuszewskiego, Zenona Fisza, Rufina Piotrowskiego, Józefa Bohdana Zaleskiego, Klementynę z Tańskich Hoffmanową, Julię z Woykowskich Molińską, Narcyzę Żmichowską, Teodora Tripplina, ks. Jana Bołoz Antoniewicza, Adama Asnyka, Felicjana Faleńskiego, Adama Szymańskiego, Faustyna Ciecierskiego i Ignacego Domeykę, Sygurda Wiśniowskiego i Jakuba Gordona, Paulinę Wilkońską i Annę Liberównę, Stanisława Przybyszewskiego i Tadeusza Micińskiego, Fryderyka Skarbka i Romana Jaworskiego, Edwarda Lubomirskiego i Stefana Grabińskiego, Marię Wirtemberską, Annę Zahorską, Marię Komornicką i Marię Grossek-Korycką. I kogo jeszcze? Dość.

Prócz Stownika języka Adama Mickiewicza nie zrealizowano żadnego projektu podobnego słownika pisarza: Norwida, Słowackiego, Krasińskiego ${ }^{23}$. Pomimo wysiłków, nie wydano francuskiej wersji prelekcji paryskich i nie zdobyto się na nowe ich tłumaczenie. Słowniki mitów i symboli - tak potrzebne u Słowackiego, Krasińskiego, Micińskiego - nie wyszły poza fazę koncepcyjną. Zbankrutowało w tak bogatym kraju jak Polska Wydawnictwo Narodowe - Ossolineum. Jest źle.

\section{Nadzieja i przeblyski}

Jest dobrze. Nie ma miesiąca, by świetnie wykształceni, młodzi ludzie, oczytani, znający języki nie pytali mnie o możliwość pisania doktoratu lub o pracę na uczelni. Trzeba im zaufać, pozwolić na samodzielność i w miarę możliwości walczyć o nich. Biblioteki internetowe i aukcje stwarzają wspaniały dostęp do rzadkich książek, choć nie zastąpi on żywego z nimi kontaktu. Powróciły „wielkie narracje” biograficzne, a to o Tuwimie, a to o Newerlym czy Nałkowskiej. Wrócą biografiści również w przestrzeń XIX w.

Pomimo absurdalnych przepisów, wprost niszczących wydawnictwa pokonferencyjne, organizujemy (i to liczne) konferencje naukowe, wydajemy książki zbiorowe, stwarzając młodym możliwość debiutu i kształcenia się w konfrontacji z autorytetami ${ }^{24}$. Instytucja tutora przegrała z instytucją Mistrza. Młodzi chcą Mistrzów, a nie opiekunów naukowych ${ }^{25}$. Nie zanika pasja zgłębiania przeszłości i prace tak o średniowiecznej, jak o romantycznej czy naturalistycznej literaturze piszą ludzie dwudziestokilkuletni, dla których ta pasja bywa całym światem.

\footnotetext{
23 Trwa tworzenie Internetowego stownika języka Cypriana Norwida (projekt: J. Puzynina, T. Korpysz, Pracownia Słownika Języka Norwida, Wydział Polonistyki, Uniwersytet Warszawski).

24 Pewną zmianę przepisów przyniosło latem $2011 \mathrm{r}$. kolejne rozporządzenie ministerialne przywracające punktację za księgi pokonferencyjne. Ale istota absurdalnego „systemu” pozostała bez zmian.

${ }_{25}$ Zob. głosy w dyskusji o Mistrzach: Bogdana Mazana, Anety Mazur, Barbary Bobrowskiej i Magdaleny Saganiak: Mistrz i uczeń, „Wiek IX” 2010, R. III (XLV).
} 
Z uznaniem patrzę na inicjatywy edytorskie ośrodka toruńskiego, lecz i warszawskie próby krytycznych edycji Prusa, poznańską edycję poezji drugiej połowy XIX w. czy niestrudzoną aktywność edytora listów Żeromskiego - Zdzisława Jerzego Adamczyka.

Whumanistyce nie było i nie będzie ośrodków wiodących. Wiodące są tylko indywidualności, których nie da się kupić za pieniądze Ministerstwa Nauki i Szkolnictwa Wyższego.

Nie chcę, by to historia kazała nam wracać po nauki do XIX w., a rozpad projektu europejskiego rzucił nas w ramiona kulturowego narcyzmu, podszytego strachem. Nigdy nie miałem i nie mam wątpliwości, że filologia polska (czy prowokacyjnie: badania nad wyobraźnią) ma sens, że przecież „nikt tego nie czyta”. Trzeba odrzucić jałowe roztrząsania o tym „po co pisać” itp. Dziś czytam studium Obraz księgarza w literaturze polskiej drugiej połowy XIX wieku, jutro poczytam o Teologii wczesnych filozofów greckich ${ }^{26}$. Zapewne i coś napiszę, ba, oto piszę teraz.

To ma sens, to jest sens: d o r a ź ny, gdy dialogujemy między sobą, choćby i nieliczni; i pon a d o raźny jako odpowiedź na list, depozyt kultury polskiej i światowej, który otrzymaliśmy od tych, co przed nami zadawali te same pytania. A jak i czy dobrze im odpowiadam, odpowiadamy, osądzi sędzia sprawiedliwy - czas. Tempus edax rerum. Wprawdzie pożera rzeczy czas, to przecież i czas połamie zęby na naszych złudzeniach i nadziejach, które tu zostawimy wnukom, Elom i Adamom, Aniom i Nataliom. Naszym następcom.

\section{Pro domo sua. Konsolacja}

Nie mam wątpliwości, że badania nad XIX w., szanując dorobek już osiągnięty, na dobre dopiero się zaczną. Lektury XIX w. nie tylko nie uznaję za skończoną, co najwyżej mogę ją uznać za - owocnie - rozpoczętą. Wymaga ona pięknej kontynuacji. Nie potrzebuję zrzędzenia i badawczej abulii, minoderii i poklasku tłumów. Nie chciałbym, by dyskusja - tak żywa o Romantyzmie i współczesnych Wokulskich - toczyła się na pięści i wyzwiska na ulicach. Takiej dyskusji nie chcę. Przecież: postęp dokonuje się tylko przez konfrontację i spór, ale sądzić i spierać się trzeba z klasą. Co to „klasa”? To wszystko, czego zabrakło na Krakowskim Przedmieściu w roku 2011.

Tych kilka myśli mogłem wygłosić w Toruniu, w środowisku Uniwersytetu Mikołaja Kopernika i Fundacji Artura Hutnikiewicza. Bardzo wiele zawdzięczam toruńskiemu środowisku naukowemu. Przemawiam - co karmi próżność i podsyca lęki - po Profesorach Starnawskim, Makowieckim, Sawickim. To z mojej strony śmiałość. Ale usprawiedliwiam się pragnieniem wyrażenia wdzięczności. Nie znałem osobiście prof. Artura Hutnikiewicza, ale kształtowałem się w świetle żywej, wzorcotwórczej opowieści o tym Uczonym, człowieku i humaniście. Opowieści, jaką snują jego Przyjaciele i Uczniowie, niektórych z nich mogę liczyć do grona moich naukowych przyjaciół: Bogdana Burdzieja, Grażynę HalkiewiczSojak, Zofię Mocarską-Tycową, Mirosława Strzyżewskiego i Bognę Paprocką-Podlasiak. Od lat znam i cenię toruńskich profesorów - Janusza Skuczyńskiego, Jerzego Speinę, Ewę

\footnotetext{
26 M. Drożdżewicz, Obraz księgarza w literaturze polskiej drugiej połowy XIX wieku, „Bibliotekarz Podlaski” 2011/2012, nr 23/24, s. 12-47; W. Jäger, Teologia wczesnych filozofów greckich, przeł. J. Wocial, przedmowa J. Domański, Kraków 2007.
} 
Owczarz; toruńskie i białostockie środowisko polonistyczne znakomicie połączyła osobowość prof. Krystyny Jakowskiej.

Prawdziwą, wieloletnią przyjaźnią złączył mnie los z prof. Marią Kalinowską, której jako człowiekowi i uczonej wiele zawdzięczam, w tym przeżycia chwil smutku i radości. Z toruńskim środowiskiem związany jest wreszcie jeden z moich Mistrzów - prof. Wojciech Gutowski, od którego jako student uczyłem się (podpatrując!) sztuki interpretacji tekstów tak trudnych, jak prace Tadeusza Micińskiego. Mistrzowi, Micińskiemu i metodzie pozostałem wierny do dziś, wzbogacając refleksję o inspiracje, jakie dała mi przyjaźń z Osobowościami tak różnymi, jak Profesor Halina Krukowska i Profesor Michał Głowiński. To też Mistrzowie.

Poruszył mnie szczerością Dziennik Artura Hutnikiewicza. Nazywać rzeczy po imieniu - piękno pięknem, łotrostwo łotrostwem - wielkość mierzyć nie skalą tytułów, wiekiem i stanowiskiem, lecz miarą wysiłku, jaki człowiek, upadając czasem, wkłada w pokonywanie słabości i poznawanie świata - to mnie wzrusza. Podobnie jak wyznanie człowieka świadomego swej pozycji i dorobku, który umie przyznać, że „niebywale trudno jest pokonać w sobie demona lenistwa. Lechoń znał go doskonale, znam go i ja”27. Ja też. Hutnikiewicz demona przegnał, zwalczył i demona czasu, starzenia się - dając wyraz myśli bezlitosnej dla głupoty w Dzienniku, który jest też pochwałą Mistrzów:

Na uroczystości było wiele przemówień, raczej kiepskich, najlepsze samego jubilata, wygłoszone z pamięci. Słuchając tych przemówień myślałem sobie, dlaczego znakomici teoretycy nauk pedagogicznych wychowują niemal z reguły tak przeciętnych uczniów, bo żaden $\mathrm{z}$ tych przemawiających, a mieniących się wychowankami profesora ponad przeciętność nie wyrósł. Czy jakakolwiek teoria wychowania zdolna jest naprawdę zapewnić produkcję jednostek twórczych o najwyższym poziomie wyrobienia umysłowego i moralnego? Czy nie jest ono zawsze rezultatem własnej pracy nad sobą, a rola wychowawcy ma sprowadzać się do dyskretnej pomocy, do wytwarzania warunków i sytuacji, w których owe uzdolnienia i dysproporcje wychowanka mogą się w pełni ujawnić i zaktywizować? I nie tyle teoria, ile osobowość mistrza, jego własne uposażenie umysłowe i formacja moralna ${ }^{28}$.

Nie jestem ani konserwatystą, ani postępowcem. Chcę być badaczem wyobraźni. Pisać swój list do wnuków, tym samym odpowiadając mej wielkiej, licznej rodzinie, która pisze do mnie z adresu nadawcy, który brzmi: wiek XIX. Także XX i XVIII, i XXI. Tak widzę dia$\log$ z tradycją i wspólnotą kultury, języka, historii i wartości, w której przyszło mi się urodzić i pracować. Pracować nad wiekiem, który nazywam, ale tylko po cichu i dla siebie, wiekiem Adama Mickiewicza.

Humanistyki bez słów zasadniczych - piękna, śmierci, miłości, cierpienia, egzystencji, snu i jawy - nie wyobrażam sobie i uprawiać nie chcę, nie będę. Pracuję z pasją, ale podług

\footnotetext{
27 A. Hutnikiewicz, Dziennik, cyt. za: B. Burdziej, Lwów w „Dzienniku” (1973) Artura Hutnikiewicza, w: Modernistyczny Lwów. Teksty życia, teksty sztuki, red. E. Paczoska, D. M. Osiński, Warszawa 2009.

${ }^{28}$ Ibidem.
} 
miarkującej wszystko myśli, którą Mickiewicz skierował do Margaret Fuller ${ }^{29}$. Powtórzę ją znów:

La littérature n'est pas la vie toute entière.

„Literatura nie jest całym życiem”.

Oto prawdziwe uspokojenie, zachęta do pracy. To Wszystko.

\section{Bibliografia}

Adam Mickiewicz. Dwa wieki kultury polskiej: Studia, red. K. Maciąg, M. Stanisz, Rzeszów: Wydawnictwo Uniwersytetu Rzeszowskiego, 2007.

Burdziej Bogdan, Lwów w „Dzienniku” (1973) Artura Hutnikiewicza”, [w:] Modernistyczny Lwów: Teksty życia, teksty sztuki, red. E. Paczoska, D. M. Osiński, Warszawa: Wydział Polonistyki Uniwersytetu Warszawskiego, 2009.

Choriew Wiktor A., Wospoitajcie Wosprijatije Rossii i russkoj litieratury polskimi pisatieliami, Moskwa: Indrik, 2012.

Dąbrowska Danuta, Okolicznościowa poezja polityczna w Polsce w latach 1980-1990, Szczecin: Wydawnictwo Naukowe Uniwersytetu Szczecińskiego, 1998.

Drożdżewicz Monika, Obraz księgarza w literaturze polskiej drugiej połowy XIX wieku, „Bibliotekarz Podlaski” 2011/2012, nr 23-24.

Dziadek Adam, Atopia: Stadność i jednostkowość, „Teksty Drugie” 2008, nr 1/2.

Ethos literatury w niespokojnym świecie, red.E. Feliksiak, Białystok: Dział Wydawnictw Filii UW, 1989.

Heine Henryk, O Polsce, przeł. W. Zawadzki, [w:] idem, Dzieła wybrane, t. 2, red. A. Sowiński, Warszawa: PIW, 1956.

Hutnikiewicz Artur, Twórczość literacka Stefana Grabińskiego: 1877-1936, Toruń-Łódź: TNT, Państwowe Wydawnictwa Naukowe, 1959.

Ilgner Artur, Byk, Kraków: Wydawnictwo i Drukarnia Towarzystwa Słowaków w Polsce, 2011.

Iwasiów Inga, Gender dla średnio zaawansowanych: Wykłady szczecińskie, Warszawa: Wydawnictwo W.A.B., 2004.

Jäger Werner W., Teologia wczesnych filozofów greckich, przeł. J. Wocial, przedmowa J. Domański, Kraków: Wydawnictwo Homini, 2007.

Janicka Anna, Małżeństwo w projekcie emancypacyjnym Gabrieli Zapolskiej, [w:] Kobieta i małżenstwo: Spoteczno-kulturowe aspekty seksualności: Wiek XIX i XX, red. A. Żarnowska i A. Szwarc, Warszawa: DiG, 2004.

Kalinowski Wojciech, Noc, marzenie i koszmar senny w twórczości Stefana Grabińskiego, [w: ] Noc: Symbol - Temat - Metafora, t. 1: Wokót "Straży nocnych" Bonawentury, red. J. Ławski, K. Korotkich, M. Bajko, Białystok: Wydawnictwo Uniwersyteckie Trans Humana, 2011.

Kasabuła Tadeusz, Ignacy Massalski: biskup wileński, Lublin: Redakcja Wydawnictw KUL, 1998.

Kopij Marta, Über Imitation zur Kreation: zur Geschichte des deutsch-polnischen romantischen Kulturtransfers, Leipzig: Leipziger Uniwersitätsverlag, 2011.

Kowalska Małgorzata, Czy trzeba nam więcej agonu? „Ponowoczesna” refleksja o roli konfliktu w kapitalizmie i demokracji, „Przegląd Filozoficzno-Literacki” 2010, nr 4.

29 A. Mickiewicz, List do Margaret Fuller, Paryż - Batignolles, 16 września [1847], cyt. za: idem, Dzieła. Wydanie Rocznicowe 1798-1998, t. XVI: Listy. Część trzecia 1842-1848, opr. M. Dernałowicz, E. Janowska, M. Zielińska, Warszawa 2004 , s. 463. 
Kowalski Grzegorz, Topika biblijna w twórczości Juliusza Stowackiego i Pära Lagerkvista: Dalekie powinowactwa, [w: ] Noc: Symbol - Temat - Metafora, t. 2: Noce polskie, noce niemieckie, red. J. Ławski, K. Korotkich, M. Bajko, Białystok: Wydawnictwo Uniwersyteckie Trans Humana, 2012.

Kowalski Grzegorz, Zygmunt Gloger: Dzieła - Recepcja - Perspektywy badań, „Bibliotekarz Podlaski” 2011/2012, nr 23/24.

Kwapiszewski Marek, Późny romantyzm i Ukraina: Z dziejów motywu i życia literackiego, Warszawa: Wydawnictwo Instytutu Badań Literackich PAN, 2006.

Lednicki Wacław, Alfred de Vigny: Z historii pesymizmu religijnego, Warszawa: Polskie Towarzystwo Wydawnicze „Zjednoczenie”, 1923.

Ławski Jarosław, Nikt: Czterdzieści i cztery głupstwa o mesjanizmie, „LiteRacje” 2011, nr 1.

Ławski Jarosław, Rok 1819: Pierwszy romantyczny program dramatu narodowego Edwarda księcia Lubomirskiego, [w:] Noc: Symbol - Temat - Metafora, t. 1: Wokót „Straży nocnych" Bonawentury, red. J. Ławski, K. Korotkich, M. Bajko, Białystok: Wydawnictwo Uniwersyteckie Trans Humana, 2011.

Ławski Jarosław, Symplifikat: Kartka z dziejów Mickiewiczowskiego mesjanizmu, [w: Romantyzm i nowoczesność, red. Michał Kuziak, Kraków: Universitas, 2009.

Ławski Jarosław, Życie i śmierć mitu: „Faust polski” między XIX a XXI wiekiem, [w:] Postacie i motywy faustyczne w literaturze polskiej, t. 2, red. H. Krukowska, J. Ławski, Białystok: Instytut Filologii Polskiej Uniwersytetu w Białymstoku, 2001.

Magnone Lena, Maria Konopnicka: Lustra i symptomy, Gdańsk: słowo/obraz terytoria, 2011.

Mencwel Andrzej, Kaliningrad, moja mitość: Dwa pokrewne eseje podróżne, Olsztyn: Borussia, 2003.

Michałowski Piotr, Głosy, formy, światy: Warianty poezji nowoczesnej, Kraków: Universitas, 2008.

Mickiewicz Adam, List do Margaret Fuller, Paryż - Batignolles, 16 września [1847], [w:] idem, Listy: Część trzecia 1842-1848, oprac. M. Dernałowicz, E. Jaworska, M. Zielińska, Warszawa: Czytelnik, 2004.

Nycz Ryszard, Możliwa historia literatury, „Teksty Drugie” 2010, nr 5.

Odmiany odmieńca: Mniejszościowe orientacje seksualne w perspektywie gender, red. T. Basiuk, D. Ferens, T. Sikora, Katowice: Śląsk, 2002.

Panuś, Kazimierz. Kaznodziejstwo w Polsce: od oświecenia do XX wieku. Kraków: Wydawnictwo M, 2001.

Szlagowski Antoni, Wady i przymioty woli ludzkiej rozebrane na tle Męki Pańskiej w sześciu konferencjach pasyjnych $w$ kościele Św. Józefa Oblubieńca (po-Karmelickim) w Warszawie roku 1899, Warszawa: Druk L. Szkaradzińskiego i S-ki, 1900.

Tur Jan, Nauka i uczony, Kraków: Gebethner i Wolff, 1917.

Twórczość Elizy Orzeszkowej w estetycznej przestrzeni wspótczesności, red. S. Musijenko, Grodno: GrGU im. J. Kupały, 2011.

Wielcy kaznodzieje Krakowa: Studia in honorem prof. Eduardi Staniek, red. K. Panuś, Kraków: Wydawnictwo UNUM, 2006.

Wiśniewska Lidia et al., Mistrz i uczeń, „Wiek XIX: Rocznik Towarzystwa Literackiego imienia Adama Mickiewicza” 2010, nr 3.

Witkowska Alina, Wielkie stulecie Polaków, Warszawa: Państwowy Instytut Wydawniczy, 1987. 


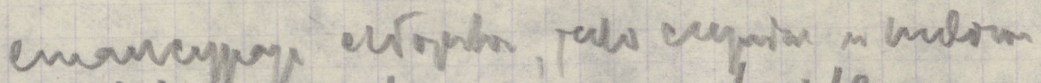

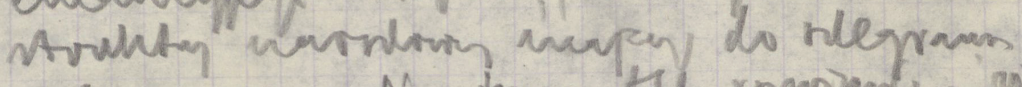

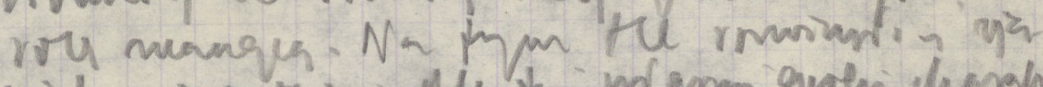

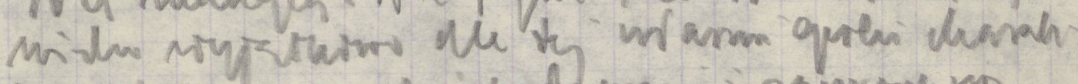

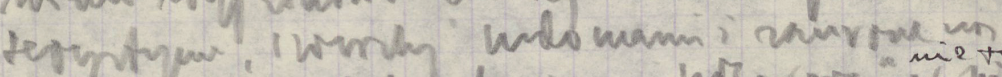

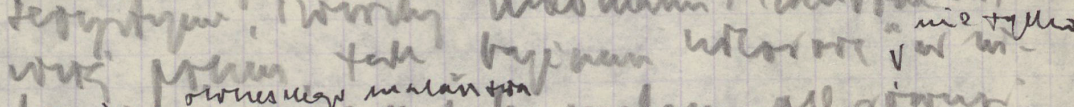

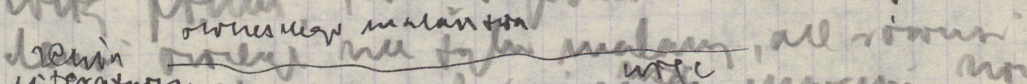

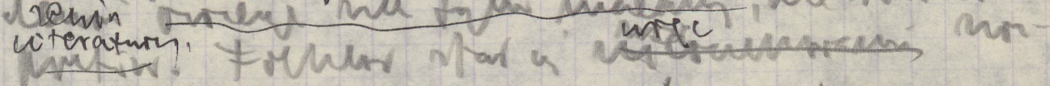

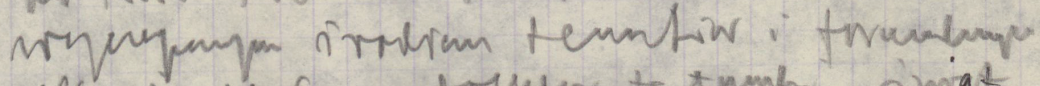

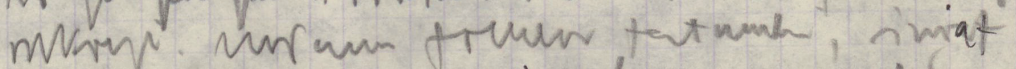

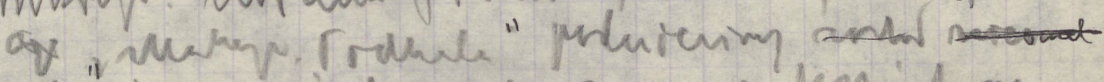

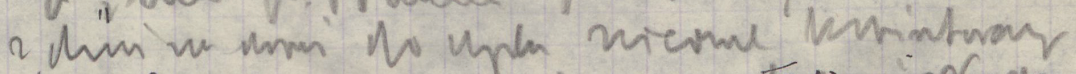

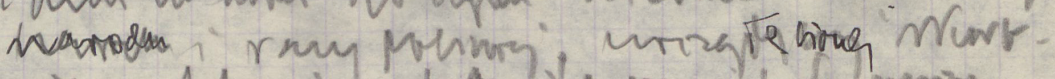

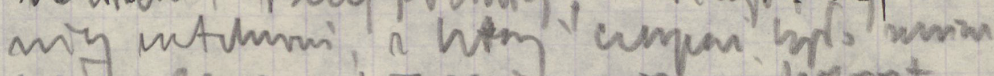

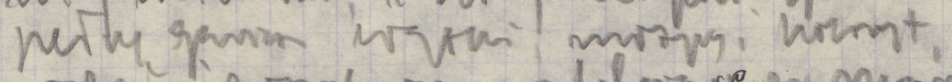

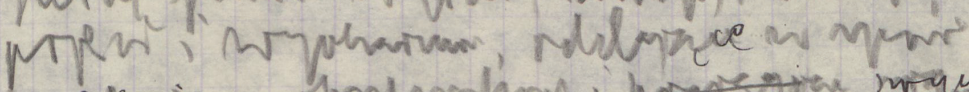

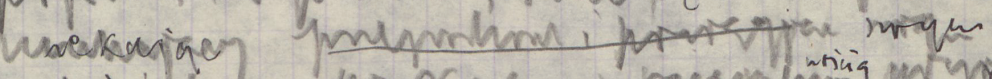

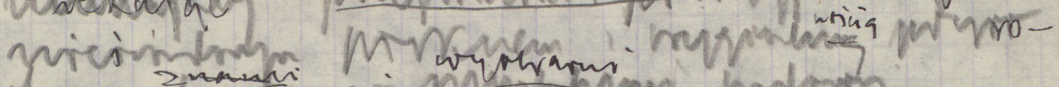
diou vimaini

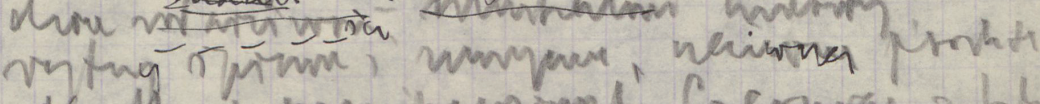

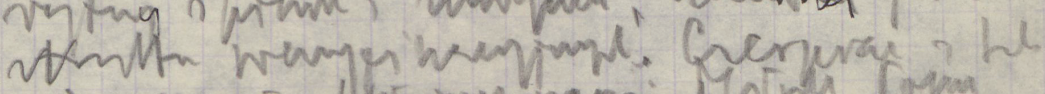

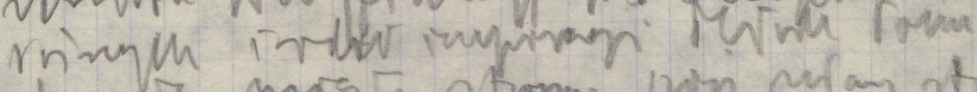

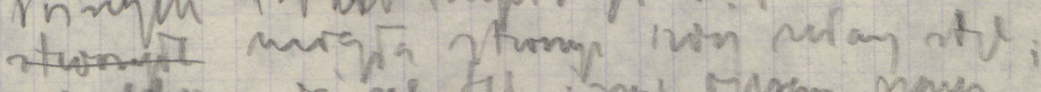

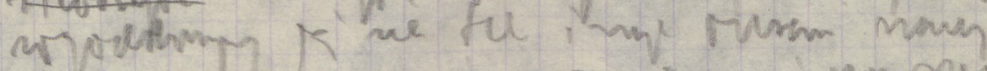

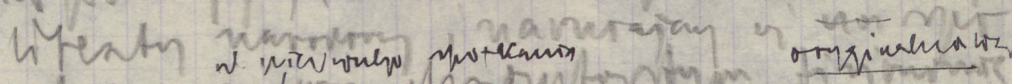

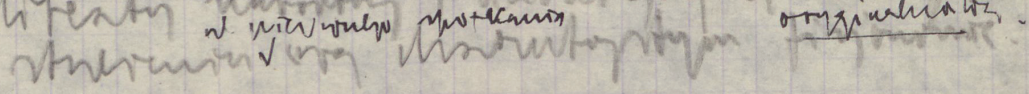

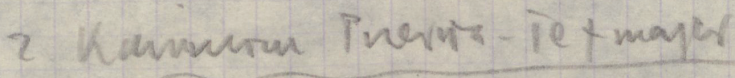

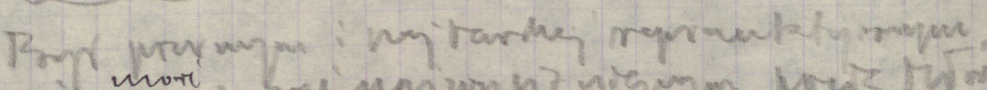

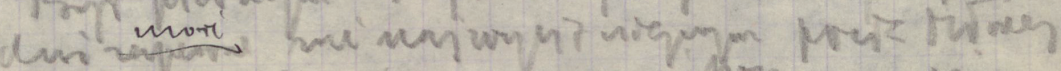

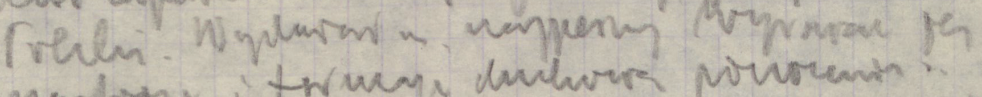

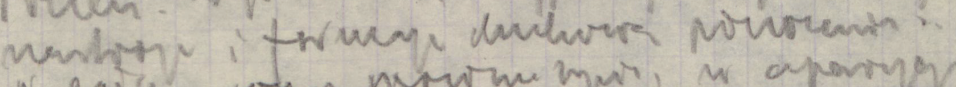

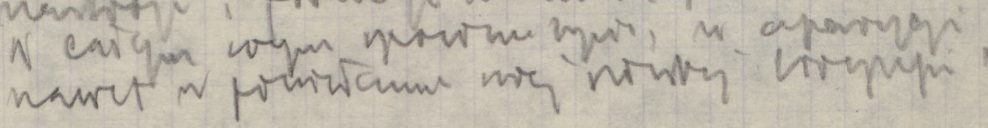

